Journal of Scientific Perspectives

Volume 3, Issue 3, Year 2019, pp. 229-236

E - ISSN: 2587-3008

URL: http://ratingacademy.com.tr/ojs/index.php/jsp

DOİ: https://doi.org/10.26900/jsp.3.024

Research Article

\title{
MULTI-CHANNEL MARINE SEISMIC SURVEY AND PRELIMINARY RESULTS OFF-SHORE KARABURUN RIDGE (WESTERN SIGACIK GULF-AEGEAN SEA)
}

\author{
Savaş GÜRÇAY* \& Günay ÇİFÇI ** \\ * Assist. Prof. Dr., Canakkale Onsekiz Mart University, Faculty of Engineering, TURKEY, \\ e-mail: savasgurcay@comu.edu.tr \\ ORCID ID: https://orcid.org/0000-0003-3402-787X \\ **Prof. Dr., Dokuz Eylul University, Instirute of Marine Sciences and Technology, TURKEY, \\ e-mail: gunay.cifci@deu.edu.tr \\ ORCID ID: https://orcid.org/0000-0002-4380-8056
}

Received: 4 April 2019; Accepted: 25 June 2019

\begin{abstract}
Sigacik Gulf is located south of Izmir (West Anatolia), the third crowded city of Turkey. The gulf is restricted by two important ridges on land from west to east, Karaburun Ridge and Seferihisar Ridge, respectively. Recent geological and geophysical studies suggested that these ridges are dominated by active strike-slip faults both on land and off-shore. This manuscript presents the results of the high resolution multi-channel seismic reflection survey which carried out onboard K. Piri Reis, research vessel of Dokuz Eylül University, off-shore Karaburun Ridge (Aegean Sea) and surroundings in August2005. Two main seismic units, lower unit and upper unit, were determined on seismic sections besides the active faults, buried faults and buried folds.
\end{abstract}

Keywords: Multi-channel seismic reflection, Karaburun Ridge, active faults 


\section{INTRODUCTION}

Western Anatolia is considered under $\mathrm{N}-\mathrm{S}$ extension in response to westward motion of Anatolian block due to the collision with the Arabian Plate [2,6] (inner map in Figure 1). As a result of this N-S extension, the Aegean region is defined by a number of E-W trending graben system and both normal and strike-slip movements exist together, which makes the area tectonically quite complex $[2,3,9,10]$.

Major tectonic structures [7, 8], focal mechanism of previous earthquakes and the main shocks of the 2005 earthquake series are shown in Figure 1. It is evident from the focal mechanisms of the events that strike-slip movements in the Gulf of Siğacık and surroundings are predominant tectonic regime $[1,11,12]$.

Two significant ridges on land are observed, Karaburun and Seferihisar Ridges. Karaburun Ridge is mainly formed by Late Paleozoic to Mesozoic units of Sakarya continent, while Seferihisar Ridge consists of Cretaceous flysch and melange associations $[4,5] .[7,8]$ suggested a positive flower structure in Siğacık Gulf and surroundings.

Urla Fault (UF), Karaburun Fault (KF), Izmir Fault (IF) and Tuzla Fault (TF) are the most important structural formations of the land area (Figure 1). The Tuzla Fault is the most prominent fault zone in the area, and can be traced for about $40 \mathrm{~km}$ from the Buca area in the north down to the Kuşadası Gulf, and consists of closely spaced subparallel faults extending from NNE to SSW [5]. Its displacement, however, is controversial, especially offshore Seferihisar area. Genç et al. [5] named this fault as Orhanlı Fault Zone and suggested an oblique displacement with sinistral strike-slip and dip-slip components at SE border of Seferihisar Ridge on land. On the other hand, using geomorphologic data, Emre et al. [4] suggested a dextral movement along the Tuzla Fault. Using multi-channel seismic data, Ocakoğlu et al. [7, 8] suggested that Karaburun Fault and Tuzla Fault have an active reverse fault characteristics related to Karaburun and Seferihisar Ridges, respectively. Urla Fault exhibits a strike-slip characteristic both on land and offshore Siğacik [7].

The study area is located off the western coast of Turkey; comprising off-shore Karaburun Ridge and surroundings (Figure 1) (western Siğacık Gulf). In the past, Siğacık Gulf and surroundings have shown significant seismic activity. Previous seismic reflection studies show that the study area is widely deformed by N-S to NE-SW trending active strike-slip faults, reverse faults and some E-W trending normal faults which are, in place to place, cut by strikeslip faults $[7,8]$.

The earthquake series occurred between 17 and 20 October 2005 in the Siğacik Gulf describes the activity of strike-slip faults in the region. Together with active faulting, some hot spots attributable to geothermal vents are common in the region, which shows that the study area is in an unstable tectonic condition [1]. 
Figure 1. Map of the study area and surroundings with seismic profiles, active faults [7,8], and focal mechanism of strong earthquakes $[1,11,12]$. Heavy lines are the seismic sections displayed in the article (Sefline-7 and Line-1). UF: Urla Fault, KF: Karaburun Fault, IF: Izmir

Fault, TF: Tuzla Fault. Inner map shows regional tectonics of Anatolian micro-plate.

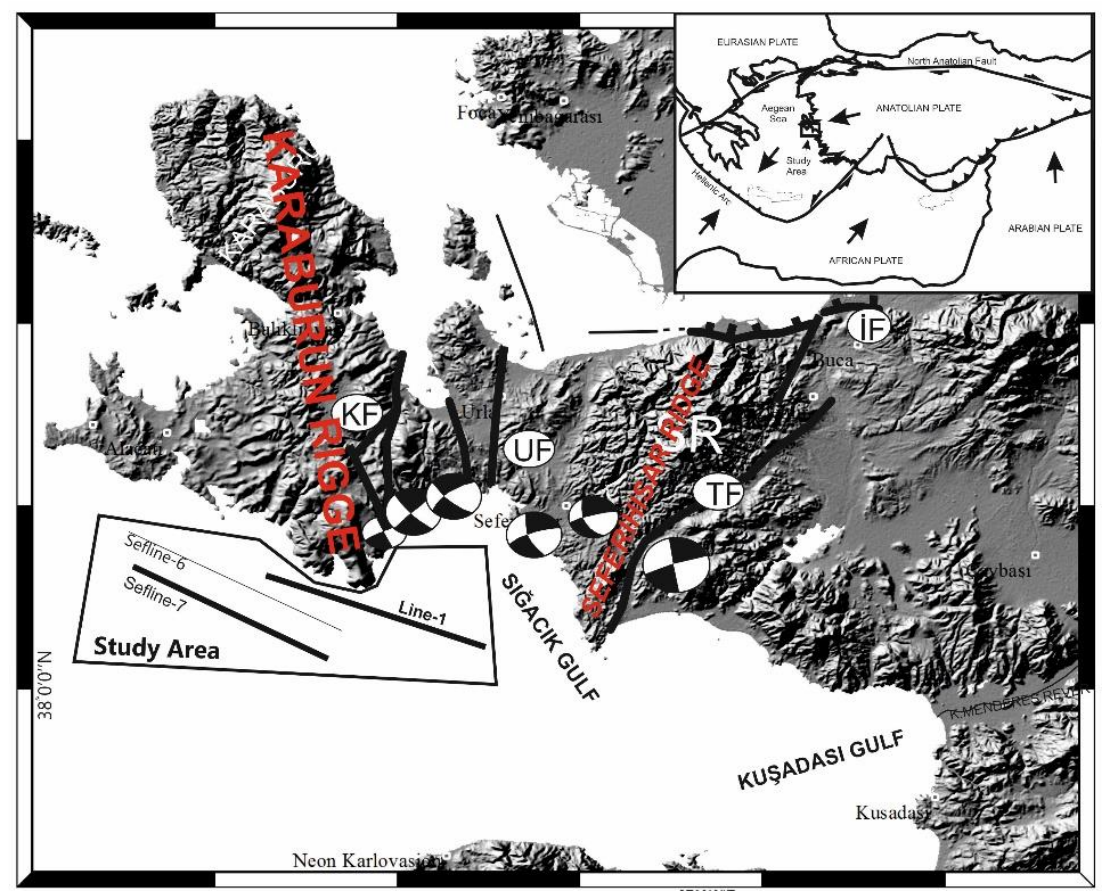

\section{SEISMIC DATA ACQUISITION AND PROCESSING}

During the cruise, the high-resolution multi-channel seismic reflection profiles were

collected using a 48-channel SeaMUX 300m long digital seismic streamer with a $6.25 \mathrm{~m}$ group interval, an NTRS-2 seismograph and the Macha gun controller of Dokuz Eylul University Institute of Marine Sciences and Technology (DEU-IMST). The source was a 105/105 in ${ }^{3}$ generator injector (GI) air gun fired every $12.5 \mathrm{~m}$. The resultant 12 -fold data were recorded digitally for 2 seconds at $1 \mathrm{~ms}$ sample rate. The seismic data were processed in the seismic laboratory of Institute of Marine Sciences and Technology (SeisLab), at Dokuz Eylul University, using the ProMAX software. The processed data were imported into the industry seismic reflection interpretation software "The Kingdom Suite". The detailed outline of the high resolution multi-channel seismic reflection system including seismic data processing and seismic data interpretation software and hardware are shown in Figure 2.

The following data processing stages were carried out: Raw Data Input, Geometry Load, Band-pass Filter (12-200 Hz), F-K Filter, CDP sort, Velocity Analysis, NMO correction, 12 Fold Stack, Kirchhoff Time Migration, Automatic Gain Control and SEG-Y Out. The recording parameters used during the survey are shown in Table 1. 
Figure 2. Outline of the high resolution multi-channel seismic reflection system of Dokuz Eylul University Institute of Marine Sciences and Technology (DEU-IMST).

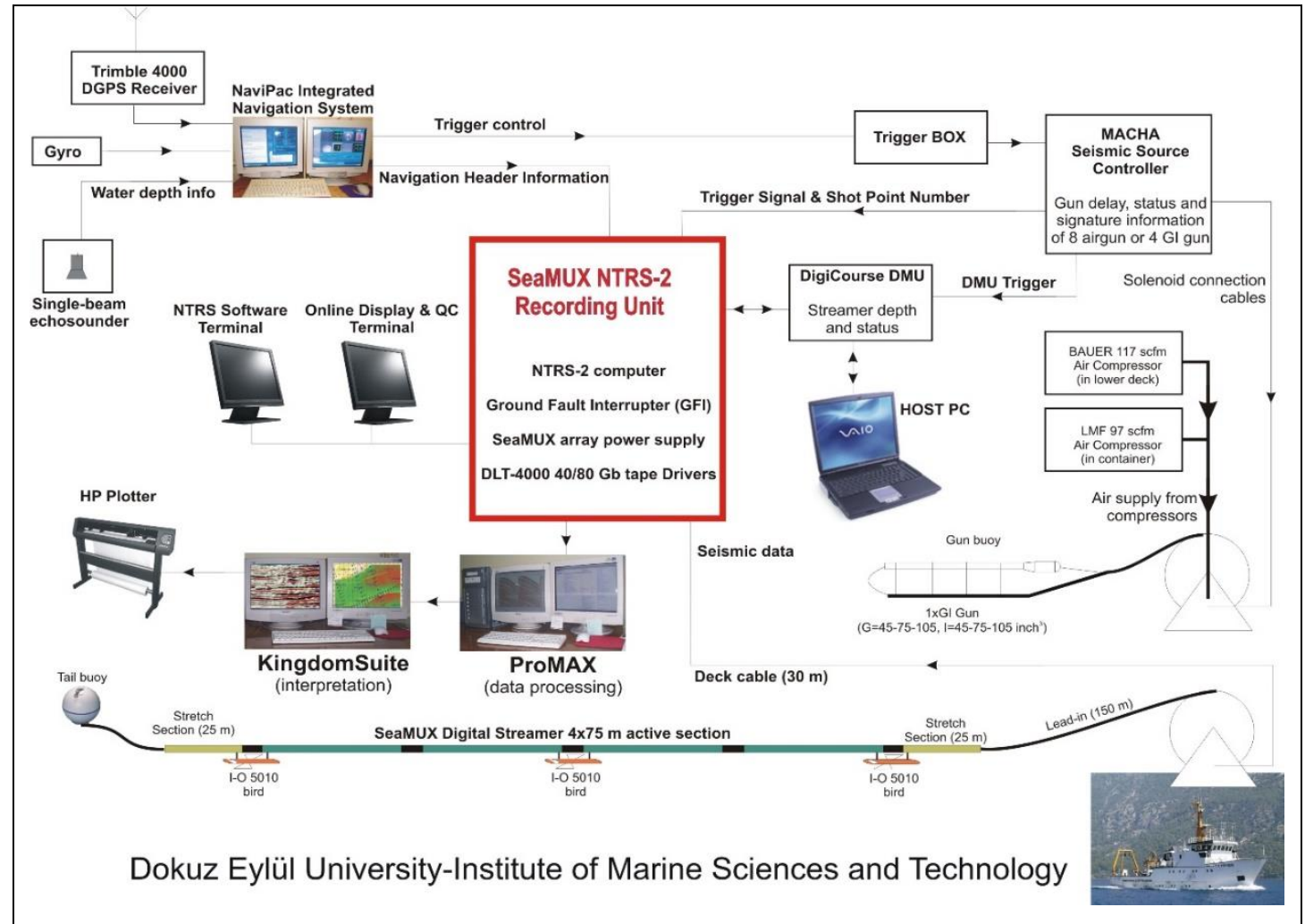

Table 1. Data acquisition parameters used during the survey.

\begin{tabular}{|c|c|}
\hline Number of Channels & 48 \\
\hline Streamer Length (m) & 300 \\
\hline Near Offset (m) & 40 \\
\hline Far Offset (m) & 340 \\
\hline Shot Interval (m) & 12.5 \\
\hline Group Interval (m) & 6.25 \\
\hline Sampling (ms) & 1 \\
\hline Record Length (s) & 2 \\
\hline Maximum Fold & 12 \\
\hline Source & GI Gun $\left(105+105\right.$ inch $\left.^{3}\right)$ \\
\hline
\end{tabular}

\section{RESULTS}

Two fundamental seismic units are observed on seismic sections (an upper and a lower unit) separated by a distinct unconformity surface indicated as UN on the interpreted seismic sections. The upper seismic unit member most likely formed by basin deposits which onlap the lower member, and has parallel to sub-parallel reflectors deformed by many near-vertical faults. The lower seismic member is defined as an acoustic basement. Because of the correlation with the seismic sections of Ocakoğlu et al. [7, 8], it is hereby interpreted that the lower and upper units represent Miocene and older rocks, and Plio-Quaternary deposits, respectively.

The faults in this study, observed from seismic sections, are considered as active and buried faults due to they cut the layers until the seafloor or not, respectively. It is observed that 
the study area is deformed generally by active and buried strike-slip faults and some of them have also normal component.

\subsection{Karaburun Ridge Area}

In the western study area (Figure 1) although we observe some active and buried faults, the density of them is lower than the eastern study area (Figure 3 and Figure 4). This area is the western part of the offshore continuation of Karaburun Ridge and Plio-Quaternary sediments are imaged as parallel to sub parallel reflectors without major deformation. That depth of the unconformity surface (UN) is almost constant at 1.300 s and shows almost no apparent relief (see Sefline7 in Figure 3).

The effect of active and buried fault zones off-shore Karaburun Fault Zone (Figure 1) is illustrated in Sefline1 (Figure 4). These faults are located at the central part of the section consisting of very dense near-vertical faults. What is important for this seismic line is that we observe some small scale folds both inside of the central fault zone and also at SE part of the line. Especially at the top of fault zone, there is an erosional area on the seabed, and just below this erosional area, fault planes unusually change their slip angles (compare the fault plane inclinations of the faults at SE and NW side of the seabed erosion zone). According to these observations, we conclude that there may be some indications of local compressional tectonics in the offshore Karaburun Ridge. 
Figure 3. Sefline7 seismic line (a) and its interpretation (b) This section shows the active and buried faults in the western part of-shore Karaburun Ridge.
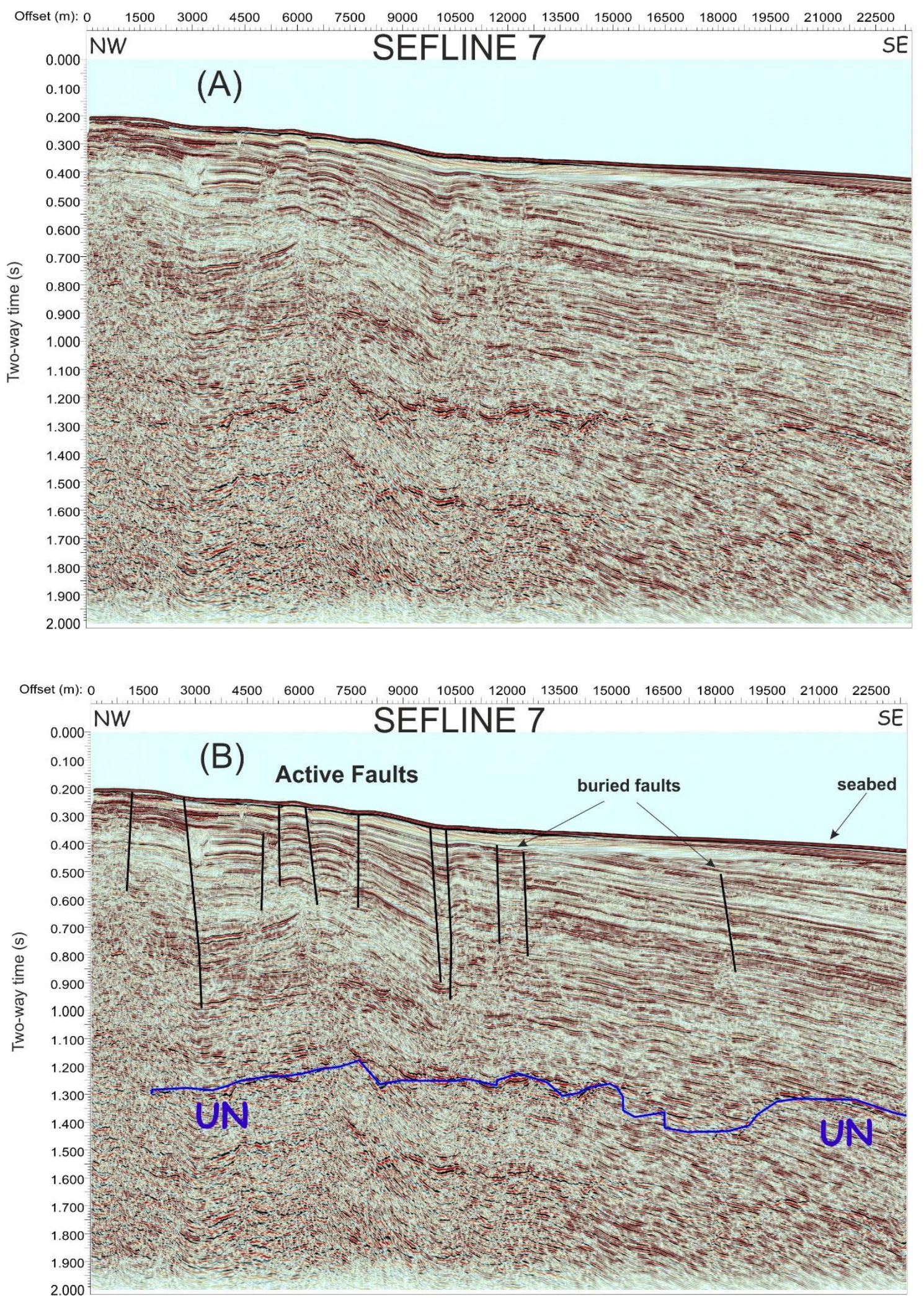
Figure 4. Seismic section Seflinel (a) and its interpretation (b) The section shows the active and buried faults off-shore Karaburun Ridge.
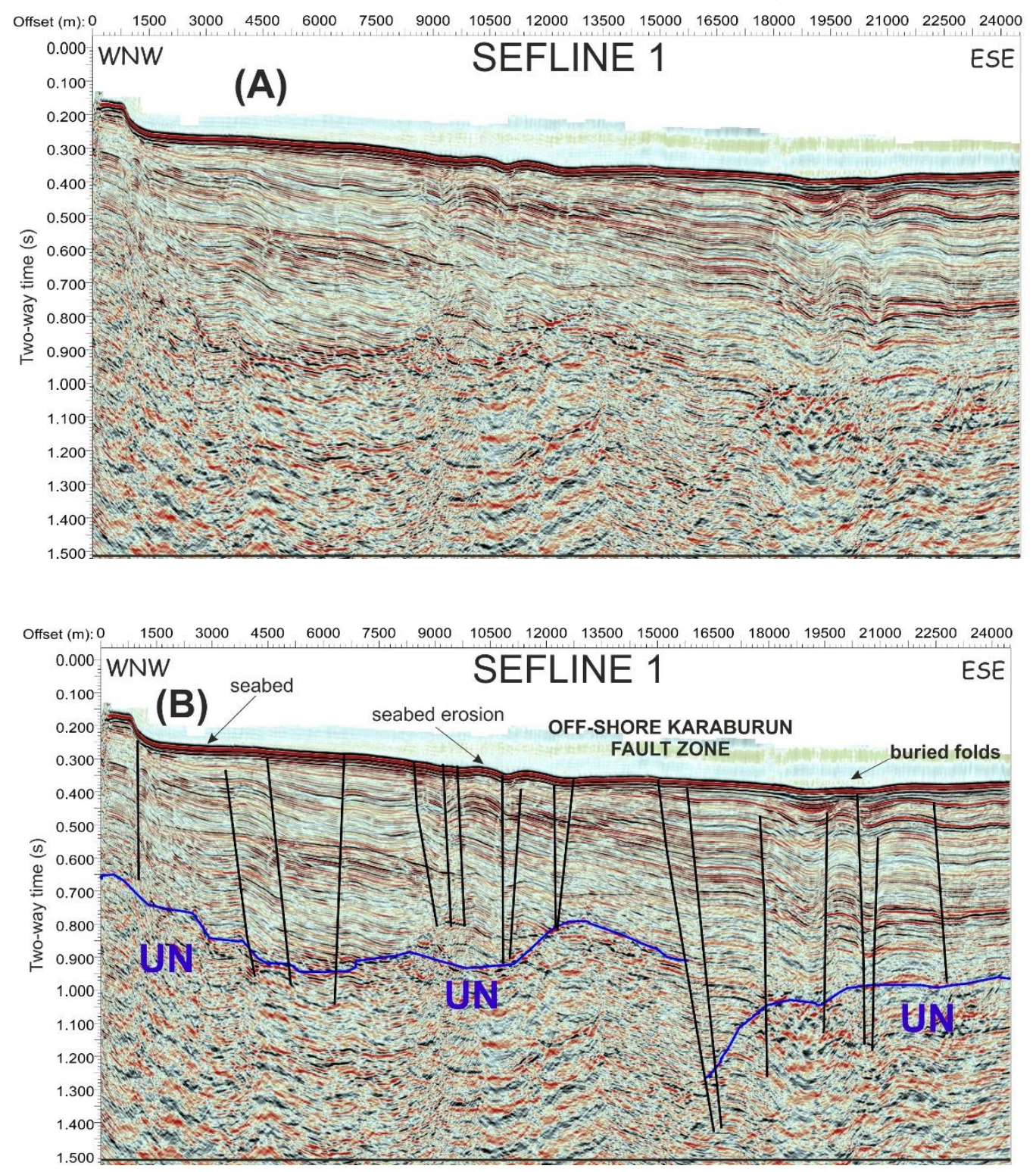

\section{CONCLUSIONS}

A high resolution multi-channel seismic survey was carried out off-shore Karaburun Ridge and surrounding areas. The seismic data collected and interpreted in this manuscript supply high resolution and quality images to demonstrate the active tectonic and related stratigraphy. This study allows us to recognize of the unconformity and discontinuity between the layers, buried faults and folds, and investigation of the deposition shape of the upper and lower units. Two main seismic units, lower unit and upper unit, were determined on seismic sections. The study area and surroundings is under the effects of some active faults, some of which have normal component.

\section{Acknowledgements}

We thank the SeisLab team, captain and crew of the R/V Koca Piri Reis research vessel of Dokuz Eylul University-Institute of Marine Sciences and Technology for their labor during data acquisition. We thank the ProMax (Halliburton) for the data processing software. We thank the IHS for Kingdom Seismic and geological interpretation software. 


\section{REFERENCES}

[1] BENETATOS, C., KIRATZI, A., GANAS, A., ZIAZIA, M., PLESSA, A. and DRAKATOS, G. (2006). Strike Slip Motions in the Gulf of Siğacık (western Turkey): Properties of the 17 October 2005 earthquake seismic sequence. Tectonophysics, 426, 263-279

[2] DEWEY, J.F. and ŞENGÖR, A.M.C. (1979). Aegean and surrounding regions. Complex multiplate and continuum tectonics in a convergent zone. Geological Society of America Bulletin, 90, 84-92.

[3] EMRE, Ö. and BARKA, A. (2000). Active Faults between Gediz Graben and Aegean Sea (İzmir Region). BADSEM 2000 Congress, İzmir.

[4] EMRE, Ö., ÖZALP, S., DOĞAN, A., ÖZAKSOY, V., YILDIRIM, C. and GÖKTAŞ, F. (2005). İzmir yakın çevresinin diri fayları ve deprem potansiyelleri, Jeoloji Etütleri Dairesi, Maden Tetkik ve Arama, Rapor No: 10754.

[5] GENÇ, C., ALTUNKAYNAK, Ş., KARACIK, Z., YAZMAN, M. and YILMAZ, Y. (2001). The Çubukludağ graben, south of İzmir: its tectonic significance in the Neogene geological evolution of the western Anatolia, Geodinamica Acta, 14, 45-55.

[6] MCKENZIE, D.P. (1972). Active tectonics of the Mediterranean region. Geophysics Journal Royal Astronomical Society, 30, 109-185.

[7] OCAKOĞLU, N., DEMIRBAĞ, E. and KUŞÇU, I. (2004). Neotectonic structures in the area offshore of Alaçati, Doğanbey and Kuşadasi (western Turkey): evidence of strikeslip faulting in the Aegean extensional province. Tectonophysics, 391, 67- 83.

[8] OCAKOĞLU, N., DEMIRBAĞ, E. and KUŞÇU, I. (2005). Neotectonic structures in Izmir Gulf and surrounding regions (western Turkey): Evidences of strike-slip faulting with compression in the Aegean extensional regime. Marine Geology, 219, 155-171.

[9] PATTON S. (1992). Active normal faulting, drainage patterns and sedimentation in southwestern Turkey. Journal of Geological Society London 149, 1031-1044.

[10] ŞAROĞLU F., EMRE Ö. and KUŞÇU İ. (1992). Active fault map of Turkey, scale 1:2.000.000.000. General Directorate of Mineral Research and Exploration.

[11] TAN, O. and TAYMAZ, T. (2001). Source parameters of November 6, 1992 Doganbey (İzmir) earthquake $(\mathrm{Mw}=6.0)$ obtained from inversion of teleseismic body-waveforms. 4th International Turkish Geology Symposium, 171.

[12] TAN, O. and TAYMAZ, T. (2003). Seismotectonics of Karaburun Peninsula and Kusadas1 Gulf: source parameters of April 2, 1996 Kusadası Gulf and April 10, 2003 Seferihisar (İzmir) earthquakes. International Workshop on the North Anatolian, East Anatolian and Dead Sea Fault Systems: Recent Progress in Tectonics and Paleoseismology and Field Training Course in Paleoseismology, Ankara, Middle East Technical University, 147. 